\title{
Family Businesses Management and Succession: A Meta-Analysis
}

\author{
Francis Mbah Takwi, Benz Enow Bate, Vivian Akosso \\ Faculty of Business Management and Sustainability, Information and Communication Technology University USA, Yaounde, Cameroon
}

Email address:

franicis.takwi@ictuniversity.org(F. M. Takwi), benz.bate@ictuniversity.org (B.E. Bate), Vivian. Akosso@ictunivetsity.org (V.Akosso)

\section{To cite this article:}

Francis Mbah Takwi, Benz Enow Bate. Family Businesses Management and Succession: A Meta-Analysis. American Journal of Operations Management and Information Systems. Vol. 5, No. 3, 2020, pp. 56-61. doi: 10.11648/j.ajomis.20200503.14

Received: September 7, 2020; Accepted: September 23, 2020; Published: September 29, 2020

\begin{abstract}
Purpose: This paper assesses how management and succession is handled in family businesses. In addition, the research seeks to find out how to manage the business succession in the family business during the transitional period of the case company. Furthermore, the objective of my research is to provide guidelines for implementing family business succession strategy. Approach: Study was a meta-analytical literature review based on the analytical and descriptive research designs used. Findings: This paper found that rewards of a family-owned business are many as are the challenges. The findings of this research indicate that family businesses are unique and they have several common characteristics that differentiate them from other businesses. This uniqueness also causes the special challenges and opportunities, which family businesses face in their operations. The most significant characteristic that separates family businesses from non-family businesses is the family's impact on the business and ownership. The unique family business characteristics, challenges and opportunities stated in the theoretical framework can be applied to the family businesses used in this research. It can be stated that both of the case companies fit the concept of a typical family business, which is unique compared to other businesses. Limitations: the design and process of sieving articles for critical review is time consuming and involves voluminous data analysis. Conclusion: Family businesses try to intersect the distinctions between family issues and business matters. This needs to be handled with utmost care as it spells the difference between success and failure. The outcomes of this research pointed out that there are mainly two obstacles concerning the family business i.e. The company does not have a proper successor, the family governance issues have an impact on the family business succession. In other words, the family governance issues which are aspects of the poor management mode and feudal family culture. Originality: There is a paucity of recent research in this area and this paper makes a contribution towards filling this gap.
\end{abstract}

Keywords: Family Businesses, Succession, Management

\section{Introduction}

The global volume of family business owners and managers is enormous, family businesses are characterized by significant levels of family involvement, often including inputs from family members [16]. Researchers have been encouraged to analyse the activities of entrepreneurs within the context of family embeddedness perspective and incorporating family dimensions for more holistic insights [7]. A family-owned business may be defined as any business in which two or more family members are involved and the majority of ownership or control lies within a family [14]. Family-owned businesses may be the oldest form of business organization. Farms were an early form of family business in which what we think of today as the private life and work life were intertwined. In urban settings it was once normal for a shopkeeper or doctor to live in the same building in which he or she worked and family members often helped with the business as needed [10].

Since the early 1980 s the academic study of family business as a distinct and important category of commerce has developed. Today family owned businesses are recognized as important and dynamic participants in the world economy [12]. Family businesses may have some advantages over other business entities in their focus on the long term, their commitment to quality (which is often associated with the family name), and their care and concern for employees. But family businesses also face a unique set 
of management challenges stemming from the overlap of family and business issues.

Additionally, family businesses often have the intention to pass the business on to the next generation and such succession issues place a great deal of stress on family firms (Miller, Wiklund \& Yu, 2019). Succession planning involves deciding who will lead the company in the next generation. Unfortunately, less than one-third of family-owned businesses survive the transition from the first generation of ownership to the second, and only 13 percent of family businesses remain in the family over 60 years. Besides that, they are facing challenges brought about by the coronavirus pandemic. "Typical family business advantages such as strong values, patience capital, long-term goals, and fast decision-making are being tested right now," says Peter Englisch, global family business leader for PwC. "The question of whether family businesses will be more resilient than others is too early to know." [15] states that most family businesses simply don't grow.

\subsection{Statement of the Problem}

Family businesses are facing challenges both internally and externally to keep pace in an increasingly competitive environment [2]. It has been noted that family businesses are notoriously harder to manage and plan than the traditional non-family entities [10]. For example, less than one-third of family-owned businesses survive the transition from the first generation of ownership to the second, and only 13 percent of family businesses remain in the family over 60 years. If family business relax in the management and succession issues in their firms, then the challenges these category of firms face will only get worse and many failures will be experienced.

\subsection{Objectives}

The general objective of this study is to assess the management and succession matters surrounding family businesses.

\subsection{Research Questions}

1. What are the various management issues faced by family businesses?

2. How is succession handled in family businesses?

\subsection{Significance of Family Businesses}

We can find family businesses all over the world with different industries and various operating systems. Observing the list of Family Business Magazine (listing the world's oldest and biggest family businesses) one could be surprised which famous and successful companies operate as family businesses, although this list is just a little teaser from the world of family businesses.

The family-owned and family operated businesses play an important role in employment and GDP production in most of the capitalist countries. They give $75-95 \%$ of enterprises and they produce $65 \%$ of the world GDP. About $90 \%$ of the enterprises in the US are in family property and have family operation (some sources say it is $2 / 3 \mathrm{rd}$. About $60 \%$ of the stock exchange listed companies are considered to be family businesses. According to the research in the EU, here the rate of family businesses is $70-80 \%$, they give $20-70 \%$ of the EU's GDP, and their participation in employment is $40-50 \%$ [7].

The group of family businesses is dominated by the enterprises of SME sector. The rate of enterprises employing less than 10 people is quite high, but we can find quite a few family businesses among the world's biggest enterprises [7].

The strong presence of family businesses is proved all over the world, at the same time due to their heterogeneity and the lack of related statistical data, we can only assume their role in economy which cannot be negligible considering their ratio.

Succession is the final test of a family enterprise. If an enterprise becomes from a one-man business into a family business, continuity becomes a unifying interest. If the enterprise is passed on while it is profitable and in good condition, it will be the main driving force for the new generation.

According to the survey of [5] involving Canadian family entrepreneurs, the main concern of entrepreneurs is related to succession. The significance of succession is also supervised by the EU. It is desirable that on this subject would be paid attention in every member state, mainly due to the role of enterprises involved in employment. According to assumptions, in the next ten years 1/3rd of European enterprises will face with the challenge of succession. Many entrepreneurs want to operate the self-founded enterprise for just a short period of time then they are planning to sell it. In certain cases it is not just the age of the entrepreneur that motivates the handover or sell. Other factors - such as personal and family reasons and changing of market conditions - also influence the decision about the handover.

The reason of succession failures is mainly the lack of planning and preparations. From those family businesses that survive, only $30 \%$ is handed over successfully to second generation of the founder-owner family. This rate is even worse in the case of the second -third and third-fourth generation. $12 \%$ of the enterprises remain in the ownership of the third generation and $4 \%$ of them remain for the fourth generation to the family. Surveys performed in the UK show that $30 \%$ of family businesses will be second generation enterprises and $2 / 3 \mathrm{rd}$ of these get into the hands of the third generation and the rate of those enterprises which survive after the third generation is $13 \%$. According to other researchers three enterprise of ten live the handover to the second generation while the third generation hands over only $15 \%$ of these enterprises [10].

\section{Methodology}

\subsection{Research Design}

The study was designed to be qualitative in nature which clearly reviewed the aspects surrounding family businesses, 
how they are managed and how succession matters are handled therein. A meta-analysis technique was adopted. Meta-analysis is a quantitative technique that uses specific measures (e.g., an effect size) to indicate the strength of variable relationships for the studies included in the analysis. The technique emphasizes results across multiple studies as opposed to results from a single investigation [13].

\subsection{Data Type}

The researcher used secondary data from research reports, libraries, Internet, journals and text books with the help of such processed data. One of the most noticeable advantages of using secondary data analysis is, its cost effectiveness. Because someone else has already collected the data, the researcher does not need to invest any money, time, or effort into the data collection stages of his or her study. Secondary data was preferred because the study was more of desk and not field oriented, given the challenges to field work which are posed by the current Covid-19 pandemic and related restrictions.

\subsection{Source of Data}

The data was obtained from libraries, bulletin boards, the Internet, Journals, Reports and textbooks on the subject matter.

\subsection{Data Collection Method}

The eight steps approach proposed by [4] was followed to identify the secondary data to use. These eight steps are in turn: "specify domain of construct, generate sample of items, collect data, purify the measure, assess reliability with new data, assess construct validity and finally develop norms" [4]. The researcher reviewed texts from different writers in textbooks, journals, newspapers, internet and reports. The study conducted a broad search (mainly using Google Scholar) for relevant studies across all free online databases, websites and knowledge repositories identified both peer reviewed and grey literature. Key phrases i.e. "family businesses", "business succession" and "Family Business Management" for searching were in English and thus returned mainly English based articles and studies though Other non-English but relevant literature was included.

A quick skimming of the abstract of the selected studies helped to exclude or include the study or drop it. Both quantitative and qualitative studies were eligible for inclusion to address the research questions since all of these studies tend to have an element of literature and discussion. The researcher selected 350 articles which were deemed relevant at the first stage.

From this, 110 articles were dropped at the title screening step and for lack of relevance. The remaining 240 articles were included for full text screening. However, the study further narrowed down to 198 articles which were published in the last 15 years for final screening and meta-analysis.

\subsection{Data Processing and Analysis}

This was done by analyzing, interpreting, comparing, reviewing and criticizing articles of different authors thus the data was processed, edited and ready for use.

\subsection{Data Presentation}

The findings were presented qualitatively by reviewing, comparing and giving a critique comparative of the views of different authors.

\subsection{Limitations}

The data collection process involved quite voluminous amounts of data and the process of sieving articles for critical review is time consuming, it requires a lot of time to collect the required information and this affects the performance of other activities.

The biggest disadvantage of performing secondary data analysis is that the secondary data set might not answer the researcher's specific research question to the degree that the research would have hoped.

\section{Findings and Discussion}

\subsection{The Various Management Issues Faced by Family Businesses}

The thin line between family and business: The ways in which individuals typically communicate within a family, for example, may be inappropriate in business situations. Likewise, personal concerns or rivalries may carry over into the work place to the detriment of the firm. In order to succeed, a family business must keep lines of communication open, make use of strategic planning tools, and engage the assistance of outside advisors as needed.

De Massis point out that the interests of a family member may not be aligned with the interest of the business. [5] For example, if a family member wants to be president but is not as competent as a non-family member, the personal interest of the family member and the wellbeing of the business may be in conflict.

Hiring and Firing Policies: Many family businesses also have trouble determining guidelines and qualifications for family members hoping to participate in the business. Some companies try to limit the participation of people with certain relationships to the family, such as in-laws, in order to minimize the potential for conflicts. Family businesses often face pressure to hire relatives or close friends who may lack the talent or skill to make a useful contribution to the business. Once hired, such people can be difficult to fire, even if they cost the company money or reduce the motivation of other employees by exhibiting a poor attitude.

Profit sharing and salary payments: Another challenge frequently encountered by family businesses involves paying salaries to and dividing the profits among the family members who participate in the firm. In order to grow, a small business must be able to use a relatively large 
percentage of profits for expansion. But some family members, especially those who are owners but not employees of the company, may not see the value of expenditures that reduce the amount of current dividends they receive.

As we can see from the above synthesis of opinions, successfully balancing the differing interests of family members and/or the interests of one or more family members on the one hand and the interests of the business on the other hand require the people involved to have the competencies, character and commitment to do this work.

\subsection{How Succession Is Handled in Family Businesses}

Another important issue relating to family businesses is succession-determining who will take over leadership and/or ownership of the company when the current generation retires or dies. [15] reports that many surveys show that one third to one half of all family businesses don't have available next-generation successors. The key to avoiding conflicts about who will take over a business is having a well-defined plan in place.

The concept of succession is embedded in family businesses. Succession is the process of related things going after the other and this kind of connection between things linked like a series. Succession comes to the major issue in most family businesses. Succession is a multistage process rather than a simple step. It is crucial to the family business whether to keep healthy on going in the long term. Similarly to the concept of family business, there is a variety of different approaches to how succession embedded in family business is perceived. According to [10], the family business succession defines as "the passing of the leadership baton from the founder to a successor who will either be a family member or a non -family member.

Webb perceives family business succession as "the process of transitioning the management or the ownership to the next generation." [16] Therefore, the family business succession consists of two processes. It includes management succession planning and ownership succession planning. The two processes can be undertaken once a time or separately. However, it was recommended that the management succession planning can be earlier than ownership succession planning since ownership succession plan supports the management succession.

Most family businesses have centralized ownership giving them the ability to make fast decisions and operate flexibly. Processing the information does not require long and divided hearing in several stages, but instead decisions are based on skills and experience. Being able to make decision independently is one of the benefits of family entrepreneurship. Combining family and business makes daily interaction more easygoing. The interaction between the family and business makes decision-making faster mostly due to the fact that the owner himself takes the risk in decision-making and is more daring than an external manager. The business leaders should take steps to gradually remove these relatives from the daily operations of the firm, including encouraging them to become involved in outside activities, arranging for them to sell some of their stock or convert it to preferred shares, or possibly restructuring the company to dilute their influence.

Morris posit that fundamental differences are identified between the nature and functioning of family-owned and managed businesses and those that are not family-controlled. [10] These differences include the time horizons of management, the implications of business failure, the degree of job security, the centralization of decision-making, accountability for decision-making, and the impact of the family system on the business system, among others. It is argued that the most significant of these differences concerns the way in which executive succession occurs, and specifically, unique aspects of the process of intergenerational transfer within family-owned businesses.

Morris notes that family business owners are encouraged to devote relatively more attention to relationship issues, and relatively less to estate and tax planning. It is suggested that a "relationship charter" be developed as a vehicle for strategically managing relationships within the family, much as relationships must be managed with suppliers or customers.

Jaskiewicz explored the idea of entrepreneurial legacy to explain how families' ability to embed founders' entrepreneurial values and spirits on to future generations help enhance the success of family businesses. [6] Through the family legacies, families nurture transgenerational entrepreneurship which describes the processes of how family businesses are passed down from one generation to the next [6].

\subsection{Family Business Challenges}

Conflicts in family businesses are usually different in nature because the members of the organization are also related to each other. The conflicts arise to the surface especially when the business is in a downturn. The economic business problems might cause conflicts inside the family. A great deal of the conflicts are related to money issues. Conflicts are usually seen as a threat for the family unity and this is why open and critical conversation might be discouraged. it is at times difficult to maintain Open and critical conversation when trying to avoid conflicts at the same time. Sometimes in family businesses a totally incompatible person might be recruited for a certain position just to protect friendly family relationships. Family members are often seen as small businesses, which avoid risks and because of that are often considered as less effective compared to companies, which have decentralized ownership and control. Family businesses use their own money in their operations and risks have direct impact on the family. The use of 'own money' in family businesses has a positive impact on risk taking and on the investment strategy and doesn't make them any less effective than non-family businesses. Family businesses avoid the use of external financial capital, which can hinder growth. Family members like to keep ownership in the hands of the family and avoid sharing equity with non-family members. The biggest family 
business challenge is succession because it includes changes concerning all three family business dimensions: family, business and ownership.

\section{Conclusion}

Family businesses are unique and they have several unique characteristics that differentiate them form other businesses. The main factor that makes family businesses unique is the family's significant impact on the business and ownership. When analyzing the interview results it was clear to see that the unique family business characteristics stated in the theoretical framework can be said to apply with the family businesses used in this research. The main characteristics separating family businesses form other businesses relate to long-term business planning, the existence of family traditions, sense of responsibility towards the business, the importance of trust, and the supportive interaction between family and business. The unique family business values are also one characteristic that separates family businesses from non-family businesses and also act as a source of competitive advantage [10].

Family businesses try to intersect the distinctions between family issues and business matters. If not done in a proper manner, they are bound to fail. If done well, they have the potential to transcend generations and even decades. Having a clear statement of goals, an organized plan to accomplish the goals, a defined hierarchy for decision-making, an established plan for succession, and strong lines of communication will help to prevent many possible problems from arising. All family members involved in the business must understand that their rights and responsibilities are different at home and at work. While family relationships and goals take precedence at home, the success of the business comes first at work.

When emotion intrudes upon work relationships, something that happens in all businesses from time to time, and the inevitable conflicts between family members arise, the manager must intervene and make the objective decisions necessary to protect the interests of the firm [3].

Lack of planning, however, is by far the most common underlying reason for a company to fail in the generational transition [1]. Strategic planning-centering around both business and family goals - is vital to successful family businesses. In fact, planning may be more crucial to family businesses than to other types of business entities, because in many cases families have a majority of their assets tied up in the business. But it is vital that the succession process be carefully planned before it becomes necessary due to the owner's illness or death.

\section{Recommendations}

Family businesses are advised to follow a five-stage process in planning for succession: initiation, selection, education, finance preparation, and transition.

1. In the initiation phase, possible successors are introduced to the business and guided through a variety of work experiences of increasing responsibility.

2. In the selection phase, a successor is chosen and a schedule is developed for the transition. Analysts almost unanimously recommend that the successor be a single individual and not a group of siblings or cousins. To some degree, by selecting a group, the existing leadership is merely postponing the decision or leaving it to the next generation to sort out.

3. During the education phase, the business owner gradually hands over the reigns to the successor, one task at a time, so that he or she may learn the requirements of the position.

4. Finance preparation involves making arrangements so that the departing management team can withdraw funds enough to retire. The more time is used in preparing for the financial implications of this transition the more likely a business will be able to avoid being burdened in the process.

5. In the transition phase, the business changes hands - the business owner removes himself or herself from the daily operations of the firm. This final stage can be the most difficult, as many entrepreneurs experience great difficulty in letting go of the family business. It helps when the business owner establishes outside interests, creates a sound financial base for retirement, and gains confidence in the abilities of the successor.

Astrachan reports that with the increasing demands of the business environment and divergent interests of next generation family members, more and more family businesses are turning to non-family management to fill the roles of CEO and President [2].

\section{References}

[1] Aspinall, E., \& As' ad, M. U. (2016). Understanding family politics: Successes and failures of political dynasties in regional Indonesia. South East Asia Research, 24 (3), 420-435.

[2] Astrachan, J. H., Keyt, A., Lane, S., \& Yarmalouk, D. (2002). Non-family CEOs in the family business: Connecting family values to business success. Proceedings FBN-ifera Helsinki, 183-199.

[3] Azmat, F, \& Fujimoto, Y (2016) Family embeddedness and entrepreneurship experience: a study of Indian migrant women entrepreneurs in Australia. Entrepreneurship \& Regional Development 28 (9-10): 630-656.

[4] Churchill Jr, G. A. (1979). A paradigm for developing better measures of marketing constructs. Journal of marketing research, 16 (1), 64-73.

[5] De Massis, A., Josi, S., Chua, J. S., Chrisman, J. J. (2014). "Ability and Willingness as Sufficiency Conditions for Family-Oriented Particularistic Behavior: Implications for Theory and Empirical Studies". Journal of Small Business Management. 52 (2): 344-364. doi: 10.1111/jsbm.12102.

[6] Jaskiewicz, P, Combs, JG, \& Rau, SB (2015) Entrepreneurial legacy: toward a theory of how some family firms nurture transgenerational entrepreneurship. Journal of Business Venturing 30 (1): 29-49. 
[7] Kansikas, J, Laakkonen, A, Sarpo, V, et al. (2012) Entrepreneurial leadership and familiness as a resource for strategic entrepreneurship. International Journal of Entrepreneurial Behavior \& Research 18 (2): 141-158.

[8] Karofsky, P. (2006). "Can Business Bring a Family Together?" Business Week. 22 February.

[9] Miller, D, Wiklund, J, \& Yu, W (2019) Mental health in the family business: a conceptual model and a research agenda. Entrepreneurship Theory and Practice 44 (1): 55-80.

[10] Morris, M. H., Williams, R. O., Allen, J. A., \& Avila, R. A. (2004). Correlates of success in family business transitions. Journal of business venturing, 12 (5), 385-401.

[11] Parasuraman, A., Zeithaml, V. A., \& Berry, L. L. (1988). Servqual: A multiple-item scale for measuring consumer perc. Journal of retailing, 64 (1), 12.
[12] Perman, S. (2006). "Taking the Pulse of Family Business." Business Week. 13 February.

[13] Shelby, L. B., \& Vaske, J. J. (2007). Perceived crowding among hunters and anglers: a meta-analysis. Human Dimensions of Wildlife, 12 (4), 241-261.

[14] Stefano, C. and Gatti, S. (2005). Banking for Family Business. Springer, March.

[15] Ward, J. L. (2007). Growing the family business: Special challenges and best practices. Family business review, 10 (4), 323-337.

[16] Webb, JW, Tihanyi, L, Ireland, RD, et al. (2009) You say illegal, I say legitimate: entrepreneurship in the informal economy. Academy of Management Review 34 (3): 492 510 . 